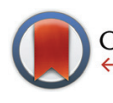

CrossMark $\leftarrow$ click for updates

Cite this: Dalton Trans., 2016, 45 3464

Received 26th November 2015, Accepted 5th January 2016

DOI: $10.1039 /$ c5dt04636j

www.rsc.org/dalton

\title{
Synthesis, structure and luminescent properties of lanthanide fluoroalkoxides $\uparrow$
}

\author{
D. M. Kuzyaev, ${ }^{\star a}$ T. V. Balashova, a,b M. E. Burin, ${ }^{a, b}$ G. K. Fukin, ${ }^{a, b}$ R. V. Rumyantcev, ${ }^{a}$ \\ A. P. Pushkarev, ${ }^{a}$ V. A. Ilichev, ${ }^{a, b}$ I. D. Grishin, ${ }^{b}$ D. L. Vorozhtsov ${ }^{b}$ and \\ M. N. Bochkarev*a,b
}

\begin{abstract}
Alkoxides $\left[\mathrm{Ln}(\mathrm{OR})_{3}(\mathrm{DME})\right]_{2}\left(\mathrm{R}=\mathrm{CH}\left(\mathrm{CF}_{3}\right)_{2}, \mathrm{Ln}=\mathrm{Sm}(\mathbf{1}), \mathrm{Yb}(\mathbf{2})\right),\left[\mathrm{Ce}(\mathrm{OR})_{3}(\text { Phen })\right]_{2}($ 3) (Phen = 1,10-phenanthroline), $\left[\mathrm{Ce}(\mathrm{OR})_{3}(\mathrm{DME})_{2}\right]_{2}\left(\mathrm{R}^{\prime}=\mathrm{C}\left(\mathrm{CF}_{3}\right)_{3}\right)(4),\left\{\mathrm{Gd}(\mathrm{OR})_{3}(\mathrm{DME})_{2}\right\}(5),\left\{\mathrm{Ln}_{2}\left[\mathrm{O}\left(\mathrm{CF}_{3}\right)_{2} \mathrm{C}-\mathrm{C}\left(\mathrm{CF}_{3}\right)_{2} \mathrm{O}\right]_{3}\right\}(\mathrm{Ln}=\mathrm{Ce}$ (6), Gd (7)), $\left\{\mathrm{Ce}_{2}\left[\mathrm{O}\left(\mathrm{CF}_{3}\right)_{2} \mathrm{C}-\mathrm{C}\left(\mathrm{CF}_{3}\right)_{2} \mathrm{O}\right]_{3}(\mathrm{Phen})_{2}\right\}$ (8), and $\left\{\mathrm{Ce}\left[\mathrm{O}\left(\mathrm{CF}_{3}\right)_{2} \mathrm{C}-\mathrm{C}\left(\mathrm{CF}_{3}\right)_{2} \mathrm{O}\right]\left[\mathrm{O}\left(\mathrm{CF}_{3}\right)_{2}-\mathrm{C}\left(\mathrm{CF}_{3}\right)_{2} \mathrm{OH}\right]\right.$ $\left.(\text { Phen })_{2}\right\}$ (9) were synthesized by the reactions of silylamides $\mathrm{Ln}\left[\mathrm{N}\left(\mathrm{SiMe}_{3}\right)_{2}\right]_{3}$ with respective fluorinated alcohols. The heterovalent trinuclear complex $\left\{\mathrm{Sm}_{2}\left(\mu_{2}-\mathrm{OR}\right)_{3}\left(\mu_{3}-\mathrm{OR}\right)_{2} \mathrm{Sm}(\mathrm{OR})_{2}(\mathrm{THF})_{2.5}\left(\mathrm{Et}_{2} \mathrm{O}\right)_{0.5}\right\}$ (10) was obtained by treatment of $\mathrm{Sml}_{2}(\mathrm{THF})_{2}$ with $\mathrm{ROK}$. The reaction of europium(॥) and yttrium(II) silylamides with $\mathrm{ROH}$ afforded the heterobimetallic alkoxide $\left\{\mathrm{Eu}_{2}\left(\mu_{2}-\mathrm{OR}\right)_{3}\left(\mu_{3}-\mathrm{OR}\right)_{2} \mathrm{Y}(\mathrm{OR})_{2}(\mathrm{DME})_{2}\right\}$ (11) containing divalent europium. The molecular structures of 1, 2, 3, 9, 10 and 11 were determined by X-ray analysis. All the prepared cerium derivatives as well as the europium-yttrium isopropoxide upon UV excitation exhibited photoluminescence in the regions of 370-425 (for $\mathrm{Ce}^{3+}$ ) and $485 \mathrm{~nm}$ (for $\mathrm{Eu}^{2+}$ ) which was assigned to $4 d \rightarrow 5 f$ transitions.
\end{abstract}

\section{Introduction}

Luminescent materials attract great attention because of their wide application in light sources and color displays, such as cell phones, computer and TV screens. In particular, organolanthanide emitters have inspired vigorous research activities owing to their long luminescence lifetimes and narrow characteristic emission bands originated from $\mathrm{f}-\mathrm{f}$ transitions, which cover the entire visible and near-infrared region. ${ }^{1}$ Besides, organic derivatives of cerium(III), gadolinium(III), europium(II), and ytterbium(II) can exhibit metal-centered emission in the UV-blue area and are attractive due to their potential application in the design of the excitation sources for chemical sensing devices, lithography, optical data recording and biomedicine. ${ }^{2}$ The short-wave metal-centered luminescence of $\mathrm{Ce}^{3+}, \mathrm{Eu}^{2+}$ and $\mathrm{Yb}^{2+}$ occurs due to $\mathrm{f}-\mathrm{d}$ transitions, which are parity-allowed, so the complexes of these metals have higher light outputs compared to $\mathrm{f}-\mathrm{f}$ emitters. ${ }^{3}$ The luminescence of $\mathrm{f}-\mathrm{d}$ transitions can be observed as well for the $\mathrm{Sm}^{2+}$ and $\mathrm{Tm}^{2+}$

\footnotetext{
${ }^{a}$ G. A. Razuvaev Institute of Organometallic Chemistry, Russian Academy of Sciences, Tropinina Street 49, 603137 Nizhny Novgorod, Russia. E-mail: mboch@iomc.ras.ru, kuzyaev@iomc.ras.ru

${ }^{b}$ Nizhny Novgorod State University, Gagarina Avenue 23/2, 603950 Nizhny Novgorod, Russia

$\dagger$ Electronic supplementary information (ESI) available: Details of X-ray experiments, crystallographic, collection and refinement data for the complexes 1-3, 9-11. CCDC 1437390-1437395. For ESI and crystallographic data in CIF or other electronic format see DOI: 10.1039/c5dt04636j
}

ions but in this case, the emission wavelength is above $650 \mathrm{~nm} .{ }^{4}$ Despite the attraction of these phosphors from the academic point of view and plausible application, the publications devoted to organolanthanide UV-blue emitters are scarce. Among the organocerium derivatives the UV luminescence was detected for the complexes of $\mathrm{CeCl}_{3}$ with crown ethers $^{5}$ and bipyridine, ${ }^{6}$ and for the pyrazinecarboxylate ${ }^{7}$ and alkylamine trifluoromethanesulfonate. ${ }^{8}$ The only known organogadolinium UV emitter is the diethylenetriaminepentaacetate, which revealed $\mathrm{f}-\mathrm{f}$ photoluminescence (PL) at $312 \mathrm{~nm} .{ }^{9}$ Shortwavelength emission of $\mathrm{Eu}^{2+}$ was found for the europium(II) chlorides and bromides with crown-ether, azacrown-ether and cryptand ligands. ${ }^{10}$ The sole organoderivative of divalent lanthanide for which the electroluminescence (EL) was documented is europium(II) bis[tris(dimethylpyrazolyl)borate]. ${ }^{11}$ The EL spectrum of this complex contains a weak band at $430 \mathrm{~nm}$, which was assigned to $\mathrm{f}-\mathrm{d}$ transition.

Recently we have reported the preparation, structures and luminescent properties of fluorinated isopropoxides of $\mathrm{Ce}(\mathrm{III})$, Eu(II)(III), Gd(III), Tm(III) and Yb(II)(III). ${ }^{12}$ The PL $\left(\lambda_{\text {em }}=330 \mathrm{~nm}\right)$ was found only for europium complex $\mathrm{Eu}_{3}\left(\mathrm{OR}^{\mathrm{F}}\right)_{7}(\mathrm{DME})_{2}$. In continuation of these studies and in search of new UV-blue phosphors, we have synthesized a set of new fluorinated isopropoxides, tert-butoxides and 2,3-butanediolates of Ce(III), $\mathrm{Sm}$ (II)(III), Eu(II), Gd(III) and Yb(III). Fluorinated alkoxide ligands were chosen because: (i) eliminating of $\mathrm{C}-\mathrm{H}$ groups (which are well known luminescence quenchers) facilitates emitting efficiency; ${ }^{13}$ (ii) fluorine substituents improve the hydrolytic 
and thermal stability, and enhance the volatility of the compounds ${ }^{14}$ which are important in the preparation of OLED devices by the vacuum deposition method; (iii) the polyfluorinated ligands can provide high-energy metal-ligand charge transfer state (MLCT) and short-wavelength emission. ${ }^{12}$

\section{Experimental section}

All experiments were performed in evacuated tubes using standard Schlenk techniques, thus excluding traces of air and water. The solvents were purified by distillation from sodium/ benzophenone ketyl (THF, DME, diethyl ether) and sodium (hexane, toluene). MeCN for electron spectroscopy, ROH, $\mathrm{R}^{\prime} \mathrm{OH}, \quad \mathrm{HO}\left(\mathrm{CF}_{3}\right)_{2} \mathrm{C}-\mathrm{C}\left(\mathrm{CF}_{3}\right)_{2} \mathrm{OH}$, 1,10-phenanthroline, and $\mathrm{Ln}\left[\mathrm{N}\left(\mathrm{SiMe}_{3}\right)_{2}\right]_{3}(\mathrm{Ln}=\mathrm{Ce}, \mathrm{Gd}, \mathrm{Sm}, \mathrm{Yb}, \mathrm{Dy}, \mathrm{Y})$, were purchased from commercial suppliers. Iodide $\mathrm{SmI}_{2}(\mathrm{THF})_{2}$ and silylamide complex $\mathrm{Eu}\left[\mathrm{N}\left(\mathrm{SiMe}_{3}\right)_{2}\right]_{2}(\mathrm{DME})_{2}$ were prepared according to the published procedures. ${ }^{15,16}$ IR spectra were recorded on a Specord M-75 instrument in the region of $4000-450 \mathrm{~cm}^{-1}$. The $\mathrm{C}, \mathrm{H}, \mathrm{N}$ elemental analyses were performed by using the Vario El cube CHNS elemental analyzer (Nizhny Novgorod State University). Yttrium and lanthanide contents were analysed by complexometric titration. Magnetic susceptibility measurements were carried out according to the procedure. ${ }^{17}$ Absorption spectra were recorded on a UV/VIS instrument "PerkinElmer Lambda-25" from 200 to $800 \mathrm{~nm}$. Emission spectra were registered from 220 to $700 \mathrm{~nm}$ on a fluorescent spectrometer "Perkin Elmer LS-55". Registration of absorption and emission spectra were performed in a $1 \mathrm{~cm}$ fluorescent quartz cuvette.

\section{$\left[\mathrm{Sm}(\mathrm{OR})_{3}(\mathrm{DME})\right]_{2}(\mathbf{1})$}

Propanol ROH (0.094 g, $0.56 \mathrm{mmol})$ was condensed to the solution of $\mathrm{Sm}\left[\mathrm{N}\left(\mathrm{SiMe}_{3}\right)_{2}\right]_{3}(0.123 \mathrm{~g}, 0.19 \mathrm{mmol})$ in $10 \mathrm{ml}$ of DME. The reaction mixture was stirred for $3 \mathrm{~h}$. The solvent was removed by condensation in vacuo and the residue was recrystallized from the mixture $\mathrm{PhCH}_{3}-\mathrm{Et}_{2} \mathrm{O}$. Yield of the product is $0.108 \mathrm{~g}$ (77\%). Anal. calcd (\%) for $\mathrm{C}_{26} \mathrm{H}_{26} \mathrm{~F}_{36} \mathrm{O}_{10} \mathrm{Sm}_{2}$ (1483.14): C, 21.06; H, 1.77; Sm, 20.28. Found (\%): C, 20.89; H, 1.74; Sm, 20.59. IR $\left(\nu, \mathrm{cm}^{-1}\right): 3654(\mathrm{w}), 3380(\mathrm{w}), 1626(\mathrm{w}), 1285(\mathrm{~m}), 1258$ (w), $1216(\mathrm{~m}), 1182(\mathrm{~m}), 1094(\mathrm{~m}), 890(\mathrm{w}), 848(\mathrm{w}), 742(\mathrm{w})$, $722(w), 687(w)$.

\section{$\left[\mathrm{Yb}(\mathrm{OR})_{3}(\mathrm{DME})\right]_{2}(2)$}

Complex 2 was prepared similarly to 1 from $\mathrm{Yb}\left[\mathrm{N}\left(\mathrm{SiMe}_{3}\right)_{2}\right]_{3}$ $(0.272 \mathrm{~g}, 0.42 \mathrm{mmol})$ and ROH $(0.215 \mathrm{~g}, 1.28 \mathrm{mmol})$. Yield of the product is $0.213 \mathrm{~g}(66 \%)$. Mp: $158-160{ }^{\circ} \mathrm{C}$. Anal. calcd (\%) for $\mathrm{C}_{26} \mathrm{H}_{26} \mathrm{~F}_{36} \mathrm{O}_{10} \mathrm{Yb}_{2}$ (1528.50): C, 20.43; $\mathrm{H}, 1.71 ; \mathrm{Yb}, 22.64$. Found (\%): C, 20.71; H, 1.95; Yb, 22.76. The IR spectrum of the product is analogous to that of complex $\mathbf{1}$.

\section{$\left[\mathrm{Ce}(\mathrm{OR})_{3}(\mathrm{Phen})\right]_{2}(3)$}

A solution of ROH $(0.209 \mathrm{~g}, 1.24 \mathrm{mmol})$ and 1,10-phenanthroline $(0.071 \mathrm{~g}, 0.39 \mathrm{mmol})$ in $10 \mathrm{ml}$ of $\mathrm{PhCH}_{3}$ was added to a solution of $\mathrm{Ce}\left[\mathrm{N}\left(\mathrm{SiMe}_{3}\right)_{2}\right]_{3}(0.238 \mathrm{~g}, 0.38 \mathrm{mmol})$ in $10 \mathrm{ml}$ of $\mathrm{PhCH}_{3}$. The reaction mixture was stirred at $70{ }^{\circ} \mathrm{C}$ for $4 \mathrm{~h}$. The precipitated yellow crystals were filtered off and washed with cold $\mathrm{PhCH}_{3}(2 \times 10 \mathrm{ml})$. Drying of the crystals gave $0.219 \mathrm{~g}$ (70\%) of complex 3. Mp: $147-148{ }^{\circ} \mathrm{C}$ (dec.). Anal. calcd (\%) for $\mathrm{C}_{42} \mathrm{H}_{22} \mathrm{Ce}_{2} \mathrm{~F}_{36} \mathrm{~N}_{4} \mathrm{O}_{6}$ (1642.82): C, 31.70; H, 1.33; Ce, 16.81; N, 3.36. Found (\%): C, 31.82; H, 1.35; Ce, 16.84; N, 3.47. IR $\left(\nu, \mathrm{cm}^{-1}\right): 3658(\mathrm{w}), 3456(\mathrm{w}), 1628(\mathrm{w}), 1593(\mathrm{w}), 1580(\mathrm{w}), 1521$ (m), 1499 (w), 1428 (w), 1286 (s), 1260 (m), 1213 (s), 1183 (s), 1126 (w), 1095 (s), 887 (m), 864 (w), 855 (m), 845 (s), $771(\mathrm{w})$, $741(\mathrm{~m}), 731(\mathrm{~m}), 687(\mathrm{~s}), 644(\mathrm{w}), 521(\mathrm{w})$.

\section{$\left[\mathrm{Ce}\left(\mathrm{OR}^{\prime}\right)_{3}(\mathrm{DME})_{2}\right]_{2}(4)$}

Complex $\mathbf{4}$ was prepared similarly to $\mathbf{1}$ from butanol $\mathrm{R}^{\prime} \mathrm{OH}$ $(0.266 \mathrm{~g}, 1.13 \mathrm{mmol})$ and $\mathrm{Ce}\left[\mathrm{N}\left(\mathrm{SiMe}_{3}\right)_{2}\right]_{3}(0.167 \mathrm{~g}, 0.27 \mathrm{mmol})$. Yield of the product is $0.197 \mathrm{~g}(72 \%)$. Mp: $171{ }^{\circ} \mathrm{C}$ (dec.). Anal. calcd (\%) for $\mathrm{C}_{40} \mathrm{H}_{40} \mathrm{Ce}_{2} \mathrm{~F}_{54} \mathrm{O}_{14}$ (2050.88): C, 23.43; H, 1.97; Ce, 13.66. Found (\%): C, 23.24; H, 1.78; Ce, 13.42. IR $\left(\nu, \mathrm{cm}^{-1}\right): 3691$ (w), $3606(\mathrm{w}), 3403(\mathrm{w}), 1231$ (s, br), 1097 (m), 1050 (s), $1017(\mathrm{w})$, 966 (s), 858 (s), 768 (m), 726 (s), 708 (m), 569 (w), $536(\mathrm{~m})$.

\section{$\left\{\mathbf{G d}\left(\mathrm{OR}^{\prime}\right)_{3}(\mathrm{DME})_{2}\right\}(5)$}

Complex 5 was prepared similarly to $\mathbf{1}$ from butanol $\mathrm{R}^{\prime} \mathrm{OH}$ $(0.173 \mathrm{~g}, 0.73 \mathrm{mmol})$ and $\mathrm{Gd}\left[\mathrm{N}\left(\mathrm{SiMe}_{3}\right)_{2}\right]_{3}(0.149 \mathrm{~g}, 0.23 \mathrm{mmol})$. Yield of the complex 5 is $0.162 \mathrm{~g}(67 \%)$. Mp: $152{ }^{\circ} \mathrm{C}$ (dec.). Anal. calcd (\%) for $\mathrm{C}_{20} \mathrm{H}_{20} \mathrm{GdF}_{27} \mathrm{O}_{7}$ (1042.58): C, 23.04; H, 1.93; Gd, 15.08. Found (\%): C, 22.91; H, 2.05; Gd, 15.43. the IR spectrum of the product is analogous to that of 4 .

\section{$\left\{\mathrm{Ce}_{2}\left[\mathrm{O}\left(\mathrm{CF}_{3}\right)_{2} \mathrm{C}-\mathrm{C}\left(\mathrm{CF}_{3}\right)_{2} \mathrm{O}\right]_{3}\right\}(6)$}

Butanediol $\mathrm{HO}\left(\mathrm{CF}_{3}\right)_{2} \mathrm{C}-\mathrm{C}\left(\mathrm{CF}_{3}\right)_{2} \mathrm{OH}(0.120 \mathrm{~g}, 0.36 \mathrm{mmol})$ was added by condensation in vacuo to a solution of $\mathrm{Ce}\left[\mathrm{N}\left(\mathrm{SiMe}_{3}\right)_{2}\right]_{3}$ $(0.140 \mathrm{~g}, 0.23 \mathrm{mmol})$ in $10 \mathrm{ml}$ THF. The reaction mixture was stirred for $3 \mathrm{~h}$. The solvent was removed by condensation in vacuo. Recrystallization of the residue from the mixture THF$\mathrm{Et}_{2} \mathrm{O}$ gave colorless crystals of complex $6(0.109 \mathrm{~g}, 76 \%)$. Mp: 110-112 ${ }^{\circ} \mathrm{C}$ (dec.). Anal. calcd (\%) for $\mathrm{C}_{18} \mathrm{Ce}_{2} \mathrm{~F}_{36} \mathrm{O}_{6}$ (1276.36): C, 16.94; Ce, 21.96. Found (\%): C, 16.79; Ce, 21.68. IR $\left(\nu, \mathrm{cm}^{-1}\right): 3684(\mathrm{w}), 1238(\mathrm{~s}, \mathrm{br}), 1052(\mathrm{w}), 936(\mathrm{~m}), 872(\mathrm{~m})$, $759(\mathrm{w}), 739(\mathrm{~m}), 720(\mathrm{~m}), 704(\mathrm{w}), 674(\mathrm{w}), 542(\mathrm{w})$.

\section{$\left\{\mathbf{G d}_{2}\left[\mathrm{O}\left(\mathrm{CF}_{3}\right)_{2} \mathbf{C}-\mathbf{C}\left(\mathrm{CF}_{3}\right)_{2} \mathbf{O}\right]_{3}\right\}$ (7)}

Complex $\mathbf{7}$ was prepared similarly to $\mathbf{1}$ from butanediol $\mathrm{HO}$ $\left(\mathrm{CF}_{3}\right)_{2} \mathrm{C}-\mathrm{C}\left(\mathrm{CF}_{3}\right)_{2} \mathrm{OH}(0.130 \mathrm{~g}, 0.39 \mathrm{mmol})$ and $\mathrm{Gd}\left[\mathrm{N}\left(\mathrm{SiMe}_{3}\right)_{2}\right]_{3}$ $(0.156 \mathrm{~g}, 0.24 \mathrm{mmol})$. Yield of the product is $0.137 \mathrm{~g}(86 \%)$. Mp: $142{ }^{\circ} \mathrm{C}$ (dec.). Anal. calcd (\%) for $\mathrm{C}_{18} \mathrm{~F}_{36} \mathrm{Gd}_{2} \mathrm{O}_{6}$ (1310.63): C, 16.50; Gd, 24.00. Found (\%): C, 16.71; Gd, 23.76. The IR spectrum of the product is analogous to that of 6 .

\section{$\left\{\mathrm{Ce}_{2}\left(\mathrm{O}\left(\mathrm{CF}_{3}\right)_{2} \mathrm{C}-\mathrm{C}\left(\mathrm{CF}_{3}\right)_{2} \mathrm{O}\right)_{3}(\mathrm{Phen})_{2}\right\}(8)$}

A solution of $\mathrm{Ce}\left[\mathrm{N}\left(\mathrm{SiMe}_{3}\right)_{2}\right]_{3}(0.243 \mathrm{~g}, 0.39 \mathrm{mmol})$ and 1,10-phenanthroline $(0.075 \mathrm{~g}, 0.42 \mathrm{mmol})$ in $10 \mathrm{ml}$ of THF was added to a solution of $\mathrm{HO}\left(\mathrm{CF}_{3}\right)_{2} \mathrm{C}-\mathrm{C}\left(\mathrm{CF}_{3}\right)_{2} \mathrm{OH}(0.207 \mathrm{~g}$, $0.62 \mathrm{mmol}$ ) in $5 \mathrm{ml}$ of THF. The reaction mixture was stirred for $3 \mathrm{~h}$. The solvent was removed by condensation in vacuo. The resulting pale-brown solid was washed with hexane $(3 \times$ $15 \mathrm{ml}$ ) and dried. Recrystallization of the residue from the mixture DME- $\mathrm{PhCH}_{3}$ gave orange crystals of complex 9 
$(0.022 \mathrm{~g}, 5 \%)$ which were isolated via decantation of the supernatant solution. After evaporation of the solvent from the mother liquor in vacuo and washing of the residue with hexane $(2 \times 10 \mathrm{ml})$, alkoxide 8 was obtained as a pale-brown solid. Yield of the product was $0.266 \mathrm{~g}$ (83\%). Mp: $135{ }^{\circ} \mathrm{C}$ (dec.). Anal. Calcd (\%) for $\mathrm{C}_{42} \mathrm{H}_{16} \mathrm{Ce}_{2} \mathrm{~F}_{36} \mathrm{~N}_{4} \mathrm{O}_{6}$ (1636.77): C, 30.82; $\mathrm{H}$, 0.99; N, 3.42. Found (\%): C, 30.94; H, 1.06; N, 3.39. IR ( $\nu$, $\mathrm{cm}^{-1}$ ): $3670(\mathrm{w}), 1674(\mathrm{w}), 1629(\mathrm{w}), 1592(\mathrm{w}), 1577(\mathrm{w}), 1520$ (m), 1500 (w), 1427 (m), 1349 (w), 1235 (s, br), 1059 (w), 987 (w), $969(\mathrm{w}), 930(\mathrm{~s}), 891(\mathrm{w}), 866(\mathrm{~s}), 846(\mathrm{~m}), 758(\mathrm{w}), 739(\mathrm{~m})$, $733(\mathrm{~s}), 716(\mathrm{~s}), 704(\mathrm{w}), 669(\mathrm{w}), 638(\mathrm{w}), 541(\mathrm{w})$.

\section{$\left\{\mathrm{Ce}\left[\mathrm{O}\left(\mathrm{CF}_{3}\right)_{2} \mathrm{C}-\mathrm{C}\left(\mathrm{CF}_{3}\right)_{2} \mathrm{O}\right]\left[\mathrm{O}\left(\mathrm{CF}_{3}\right)_{2} \mathrm{C}-\mathrm{C}\left(\mathrm{CF}_{3}\right)_{2}(\mathrm{OH})\right](\mathrm{Phen})_{2}\right\}(9)$}

A solution of $\mathrm{Ce}\left[\mathrm{N}\left(\mathrm{SiMe}_{3}\right)_{2}\right]_{3}(0.100 \mathrm{~g}, 0.16 \mathrm{mmol})$ and 1,10phenanthroline $(0.058 \mathrm{~g}, 0.32 \mathrm{mmol})$ in $10 \mathrm{ml}$ of THF was added to a solution of $\mathrm{HO}\left(\mathrm{CF}_{3}\right)_{2} \mathrm{C}-\mathrm{C}\left(\mathrm{CF}_{3}\right)_{2} \mathrm{OH}(0.108 \mathrm{~g}$, $0.32 \mathrm{mmol}$ ) in $5 \mathrm{ml}$ of THF. The reaction mixture was stirred for $3 \mathrm{~h}$. The solvent was removed by condensation in vacuo. The resulting pale-brown solid was washed with hexane $(3 \times$ $15 \mathrm{ml}$ ) and dried. Recrystallization of the product from the mixture DME- $\mathrm{PhCH}_{3}$ gave complex 9 as orange crystals (0.110 g, 59\%). Mp: 180-185 ${ }^{\circ} \mathrm{C}$ (dec.). Anal. Calcd (\%) for $\mathrm{C}_{36} \mathrm{H}_{17} \mathrm{CeF}_{24} \mathrm{~N}_{4} \mathrm{O}_{4}$ (1165.62): C, 37.09; H, 1.47; N, 4.81. Found (\%): C, 37.27; H, 1.53; N, 4.65. IR $\left(\nu, \mathrm{cm}^{-1}\right)$ : 3085 (w), 1627 (w), 1592 (w), 1577 (w), 1518 (s), 1497 (w), 1426 (s), 1228 (s, br), 986 (m), $960(\mathrm{w}), 927(\mathrm{~s}), 866$ (s), 848 (s), 773 (w), 731 (s), 713 (m), $686(\mathrm{w}), 637(\mathrm{w}), 528(\mathrm{w}, \mathrm{br}), 467(\mathrm{w})$.

\section{$\left\{\mathrm{Sm}_{2}\left(\mu_{2}-\mathrm{OR}\right)_{3}\left(\mu_{3}-\mathrm{OR}\right)_{2} \mathrm{Sm}(\mathrm{OR})_{2}(\mathrm{THF})_{2.5}\left(\mathrm{Et}_{2} \mathrm{O}\right)_{0.5}\right\}(10)$}

A solution of $\mathrm{SmI}_{2}(\mathrm{THF})_{2}(0.351 \mathrm{~g}, 0.64 \mathrm{mmol})$ in $10 \mathrm{ml}$ of THF was added to a solution of ROK (prepared from $0.050 \mathrm{~g}$ $(1.25 \mathrm{mmol})$ of $\mathrm{KH}$ and $0.236 \mathrm{~g}(1.40 \mathrm{mmol})$ of $\mathrm{ROH}$ according to the known procedure) in $10 \mathrm{ml}$ of THF. The reaction mixture was stirred for $5 \mathrm{~h}$. The precipitate of KI was filtered off and the solvent from the resulting solution was removed by condensation in vacuo. The residue was extracted with diethyl ether $(4 \times 10 \mathrm{ml})$. After concentrating and cooling of the extract, dark red crystals of $10(0.155 \mathrm{~g}, 40 \%)$ were obtained. $\mu_{\text {eff }}=2.91 \mu_{\mathrm{B}}$. Anal. calcd (\%) for $\mathrm{C}_{33} \mathrm{H}_{32} \mathrm{~F}_{42} \mathrm{O}_{10} \mathrm{Sm}_{3}$ (1837.61): C, 21.57; H, 1.76; Sm, 24.55. Found (\%): C, 21.29; H, 1.70; Sm, 24.84. The IR spectrum of the product is similar to that of complex 1.

\section{$\left\{\mathrm{Eu}_{2}\left(\boldsymbol{\mu}_{2}-\mathrm{OR}\right)_{3}\left(\boldsymbol{\mu}_{3}-\mathrm{OR}\right)_{2} \mathrm{Y}(\mathrm{OR})_{2}(\mathrm{DME})_{2}\right\}$ (11)}

A solution of $\mathrm{ROH}(0.158 \mathrm{~g}, 0.94 \mathrm{mmol})$ in $5 \mathrm{ml}$ of $\mathrm{Et}_{2} \mathrm{O}$ was added slowly to a solution of $\mathrm{Y}\left[\mathrm{N}\left(\mathrm{SiMe}_{3}\right)_{2}\right]_{3}(0.072 \mathrm{~g}$, $0.13 \mathrm{mmol})$ and $\mathrm{Eu}\left[\mathrm{N}\left(\mathrm{SiMe}_{3}\right)_{2}\right]_{2}(\mathrm{DME})_{2}(0.157 \mathrm{~g}, 0.24 \mathrm{mmol})$ in $10 \mathrm{ml}$ of $\mathrm{Et}_{2} \mathrm{O}$. The reaction mixture was stirred for $3 \mathrm{~h}$. The product was obtained as pale greenish-yellow crystals after concentrating and cooling of the resulting solution (0.115 g, 55\%). Mp: $208-210{ }^{\circ} \mathrm{C}$ (dec.). Anal. calcd (\%) for $\mathrm{C}_{29} \mathrm{H}_{27} \mathrm{Eu}_{2} \mathrm{~F}_{42} \mathrm{O}_{11} \mathrm{Y}$ (1742.28): C, 19.99; H, 1.56. Found (\%): C, 20.28; H, 1.80. The IR spectrum of the product is similar to that of the complex 1 .

\section{Device fabrication}

The three-layer device of structure ITO/TPD (30 nm)/complex 3 (50 nm)/BATH $(20 \mathrm{~nm}) / \mathrm{Yb}$, consisting of triphenyldiamine derivative (TPD) as a hole transport layer, 4,7-diphenyl1,10-phenanthroline (BATH) as an electron-transporting and hole-blocking layer and the lanthanide complex as an emission layer, was fabricated in a vacuum chamber $\left(10^{-6}\right.$ mbar $)$ with different resistive heaters for organic and metal layers. A commercial ITO on a glass substrate with $5 \Omega$ sq. $^{-1}$ was used as the anode material (Luminescence Technology Corp.) and commercial Yb, 99.9\% trace metal basis (Sigma-Aldrich) as the cathode material. The deposition rate for the organic compounds and metallocomplex was $1 \mathrm{~nm} \mathrm{~s}^{-1}$. The active area of the device was $5 \times 5 \mathrm{~mm}$. The EL spectra and current-voltage characteristics were measured using an Ocean Optics USB-2000 fluorimeter, the computer controlled GW Instek PPE 3323 power supply and a GW Instek GDM 8246 digital multimeter under ambient conditions.

\section{Results and discussion}

\section{Synthesis}

Isopropoxides 1 and 2 were prepared by reactions of respective silylamides $\operatorname{Ln}\left[\mathrm{N}\left(\mathrm{SiMe}_{3}\right)_{2}\right]_{3}(\mathrm{Ln}=\mathrm{Sm}, \mathrm{Yb})$ and hexafluoroisopropanol in DME solution. To synthesize cerium isopropoxide 3 in the reaction mixture phenanthroline was added. Note that complexes 1 and 2 have been prepared earlier, ${ }^{18}$ but their structures and luminescent properties have not been studied.

The products were isolated from the ether-toluene mixture as microcrystalline powders soluble in THF, diethyl ether, and DME. Unlike hydrolyzed and nonsublimable $\mathbf{1}$ and 2, cerium isopropoxide $\mathbf{3}$, due to the presence of the shielding phenanthroline at the metal center, is relatively stable in air and can be sublimed in vacuo without decomposition which made it possible to design the OLED device on its base and study the EL properties (vide infra).

$$
\begin{aligned}
& \begin{array}{r}
2 \mathrm{Ln}\left[\mathrm{N}\left(\mathrm{SiMe}_{3}\right)_{2}\right]_{3}+6 \mathrm{ROH} \underset{-6 \mathrm{HN}\left(\mathrm{SiMe}_{3}\right)_{2}}{\stackrel{\mathrm{Dn}}{\longrightarrow}} \quad\left[\operatorname{Ln}(\mathrm{OR})_{3}(\mathrm{DME})\right]_{2} \\
\mathrm{Sm}(\mathbf{1}), \mathrm{Yb}(2)
\end{array} \\
& 2 \mathrm{Ce}\left[\mathrm{N}\left(\mathrm{SiMe}_{3}\right)_{2}\right]_{3}+6 \mathrm{ROH}+2 \text { Phen } \underset{-6 \mathrm{HN}\left(\mathrm{SiMe}_{3}\right)_{2}}{\stackrel{\mathrm{PhCH}_{3}}{\longrightarrow}} \\
& \longrightarrow\left[\mathrm{Ce}(\mathrm{OR})_{3}(\mathrm{Phen})\right]_{2}
\end{aligned}
$$

X-ray analysis revealed that complexes $\mathbf{1}$ and $\mathbf{2}$ are centrosymmetrical, and isostructural dimeric compounds (Fig. 1) and have the arrangement quite analogous to that of the Ce and Tm isopropoxides reported earlier. ${ }^{12}$ In alkoxides 1 and 2 two lanthanide ions are linked via two bridging $\mu_{2}$-OR groups, each ion is bonded with two terminal isopropoxide groups and one DME molecule. The terminal Ln-O distances (2.130(5)2.182(4) in 1 and 2.068(3)-2.092(3) A in 2) are notably shorter compared to the bridging ones (2.368(4)-2.408(3) in 1 and $2.279(3)-2.284(3)$ in 2$)$. The $\mathrm{Yb} \cdots \mathrm{Yb}$ distance in 2 is equal to 


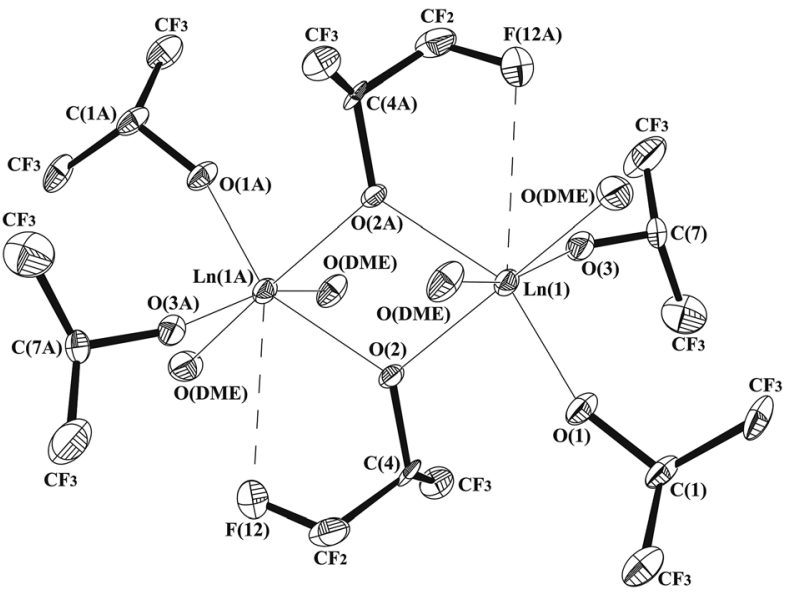

Fig. 1 Molecular structures of $1(\mathrm{Ln}=\mathrm{Sm})$ and $2(\mathrm{Ln}=\mathrm{Yb})$. Thermal ellipsoids are drawn at the $30 \%$ probability level. $\mathrm{H}$ atoms are omitted for clarity. Selected distances [Å] and angles [ $\left[^{\circ}\right]$ in 1: $\mathrm{Sm}(1)-O(3) 2.130(5)$, $\mathrm{Sm}(1)-\mathrm{O}(1)$ 2.182(4), Sm(1)-O(2) 2.368(4), Sm(1)-O(2A) 2.408(3), Sm(1)-O(5) 2.459(4), $\quad \mathrm{Sm}(1)-\mathrm{O}(4) \quad 2.514(4), \quad \mathrm{Sm}(1)-\mathrm{F}(12 \mathrm{~A}) \quad 2.852(4), \quad \mathrm{Sm}(1)-\mathrm{Sm}(1 \mathrm{~A})$ 3.9452(9); O(3)-Sm(1)-O(1) 101.43(16), O(3)-Sm(1)-O(2) 106.75(17), O(1)$\mathrm{Sm}(1)-\mathrm{O}(2) \quad 85.29(14), \mathrm{O}(3)-\mathrm{Sm}(1)-\mathrm{O}(2 \mathrm{~A})$ 100.55(15), O(1)-Sm(1)-O(2A) 149.75(15), O(2)-Sm(1)-O(2A) 68.59(15), O(3)-Sm(1)-F(12A) 75.66(15), O(1)$\mathrm{Sm}(1)-F(12 A)$ 146.17(13), $O(2)-S m(1)-F(12 A)$ 128.20(11), O(2A)-Sm(1)-F(12A) 60.40(12); in 2: $\mathrm{Yb}(1)-\mathrm{O}(3)$ 2.068(3), $\mathrm{Yb}(1)-\mathrm{O}(1)$ 2.092(3), $\mathrm{Yb}(1)-\mathrm{O}(2)$ 2.279(3), $\mathrm{Yb}(1)-\mathrm{O}(2 \mathrm{~A}) 2.284(3), \mathrm{Yb}(1)-\mathrm{O}(4)$ 2.356(4), $\mathrm{Yb}(1)-\mathrm{O}(5)$ 2.388(4), $\mathrm{Yb}(1)-F(12 A)$ 3.056(4), $\mathrm{Yb}(1)-\mathrm{Yb}(1 \mathrm{~A})$ 3.7294(4); O(3)-Yb(1)-O(1) 100.84(13), $\mathrm{O}(3)-\mathrm{Yb}(1)-\mathrm{O}(2) \quad$ 105.48(13), $\quad \mathrm{O}(1)-\mathrm{Yb}(1)-\mathrm{O}(2) \quad 87.84(13), \quad \mathrm{O}(3)-\mathrm{Yb}(1)-$ $\mathrm{O}(2 \mathrm{~A})$ 99.36(12), $\mathrm{O}(1)-\mathrm{Yb}(1)-\mathrm{O}(2 \mathrm{~A})$ 153.56(13), O(2)-Yb(1)-O(2A) 70.38(12), $\mathrm{O}(3)-\mathrm{Yb}(1)-\mathrm{F}(12 \mathrm{~A}) \quad 69.49(11), \mathrm{O}(1)-\mathrm{Yb}(1)-\mathrm{F}(12 \mathrm{~A})$ 145.07(13), O(2)-Yb(1)$\mathrm{F}(12 \mathrm{~A}) \quad 126.93(11), \quad \mathrm{O}(2 \mathrm{~A})-\mathrm{Yb}(1)-\mathrm{F}(12 \mathrm{~A}) \quad$ 59.30(10). Symmetry transformations were used to generate equivalent atoms: $-x+1,-y+1$, $-z+1$ in 1 and 2 .

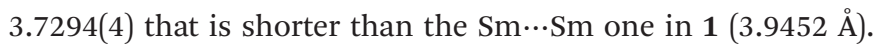
It is interesting to note that there are close intramolecular contacts $\operatorname{Sm}(1) \cdots \mathrm{F}(12 \mathrm{~A})(\mathrm{Sm}(1 \mathrm{~A}) \cdots \mathrm{F}(12))$ in 1 whereas the analogous interactions in 2 are absent. Really, the $\mathrm{Yb}(1) \cdots \mathrm{F}(12 \mathrm{~A})$ distance in 2 is 3.056(4) $\AA$ and notably exceeds the analogous one in $1(2.852(4) \AA)$. According to the literature data, ${ }^{19-22}$ typical interval values for intramolecular $\mathrm{Yb} \cdots \mathrm{F}$ and $\mathrm{Sm} \cdots \mathrm{F}$ interactions are 2.48(1)-2.726(9) $\AA$ and 2.537(2)-2.813(3) $\AA$ respectively. Besides, the intramolecular $\operatorname{Sm}(1 \mathrm{~A}) \cdots \mathrm{F}(12)$ interaction leads to elongation of the $\mathrm{C}(6 \mathrm{~A})-\mathrm{F}(12 \mathrm{~A})(1.364(7) \AA)$ bond length compared to other distances in this $\mathrm{CF}_{3}$ group (1.317(8)-1.329(8) $\AA)$. In order to understand why the intramolecular $\mathrm{Yb}(1 \mathrm{~A}) \cdots \mathrm{F}(12)$ interactions are absent in 2 , we have analyzed the saturation of the metal coordination sphere

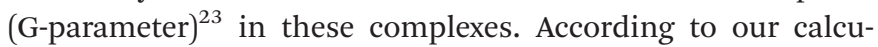
lations the saturation of the metal coordination sphere by ligands in 2 is 97.3 (2)\% that markedly exceeds the analogous one in 1 (94.9 (2)\%). Thus, there is insufficient room around the metal in 2 to realize an additional $\mathrm{Yb} \cdots \mathrm{F}$ interaction. In other words, steric factors inhibit realization of the intramolecular $\mathrm{Yb} \cdots \mathrm{F}$ contact in 2 .

According to X-ray data complex $\mathbf{3}$ has a centrosymmetrical, dimeric structure (Fig. 2a) which is close to that of $\mathbf{1}$ and $\mathbf{2}$.
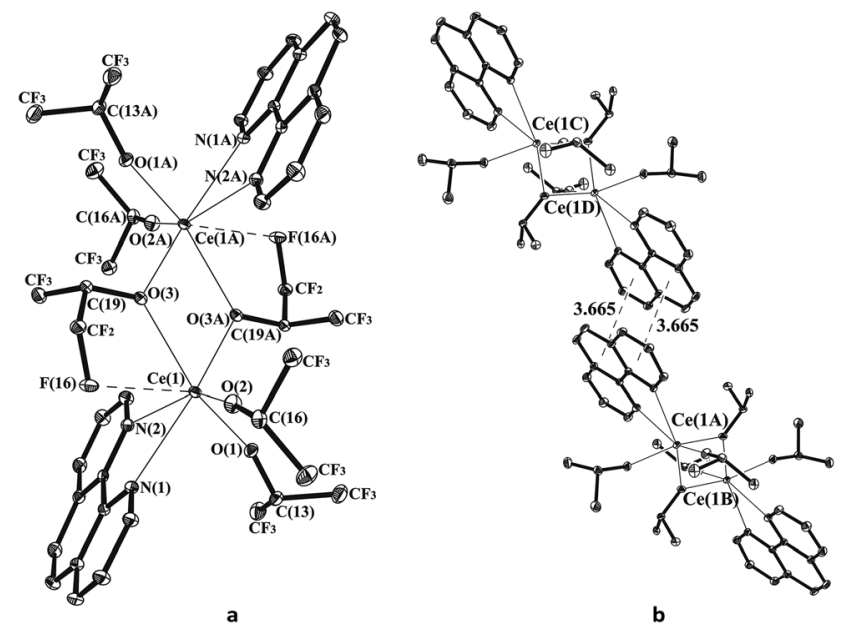

Fig. 2 Molecular structure of 3 (a) and the dimeric structure of 3 in crystal (b). Thermal ellipsoids are drawn at the $30 \%$ probability level. $\mathrm{H}$ atoms are omitted for clarity. Selected distances [Å] and angles [ $\left[^{\circ}\right]$ in 3 : $\mathrm{Ce}(1)-\mathrm{O}(2)$ 2.2064(15), $\mathrm{Ce}(1)-\mathrm{O}(1)$ 2.2340(15), Ce(1)-O(3A), 2.4394(15) $\mathrm{Ce}(1)-\mathrm{O}(3)$ 2.5249(15), Ce(1)-N(1) 2.6488(18), Ce(1)-N(2) 2.6567(17), $\mathrm{Ce}(1)-\mathrm{F}(16) \quad 2.9182(14), \quad \mathrm{Ce}(1)-\mathrm{Ce}(1 \mathrm{~A}) \quad 4.1305(2) ; \quad \mathrm{O}(2)-\mathrm{Ce}(1)-\mathrm{O}(1)$ 99.46(6), O(2)-Ce(1)-O(3A) 113.65(6), O(1)-Ce(1)-O(3A) 88.35(6), O(2)$\mathrm{Ce}(1)-\mathrm{O}(3) \quad 99.96(6), \quad \mathrm{O}(1)-\mathrm{Ce}(1)-\mathrm{O}(3) \quad$ 153.53(6), O(3A)-Ce(1)-O(3) 67.40(6), O(2)-Ce(1)-N(1) 87.50(6), O(1)-Ce(1)-N(1) 84.37(6), O(3A)$\mathrm{Ce}(1)-\mathrm{N}(1) \quad 158.54(5), \quad \mathrm{O}(2)-\mathrm{Ce}(1)-\mathrm{F}(16) \quad 76.00(5), \quad \mathrm{O}(1)-\mathrm{Ce}(1)-\mathrm{F}(16)$ 144.16(5), O(3A)-Ce(1)-F(16) 126.44(4), O(3)-Ce(1)-F(16) 59.06(4).

The main difference of complex $\mathbf{3}$ from 1 and 2 lies in coordination phenanthroline molecules instead of the DME ones. Cerium ions are linked by two $\mu_{2}$-bridged OR ligands. Each metal ion is bound to two terminal isopropoxide groups and one phenanthroline molecule. The distance $\mathrm{Ce} \cdots \mathrm{Ce}(1 \mathrm{~A})$ $(4.1305(2) \AA)$ is slightly longer than that in the complex $\mathrm{Ce}_{2}(\mathrm{OR})_{6}(\mathrm{DME})_{2}(4.064 \AA) .{ }^{12}$ As in $\mathbf{1}$ the intramolecular Ce $\cdots \mathrm{F}$ interactions in 3 are realized. The $\mathrm{Ce}(1) \cdots \mathrm{F}(16)$ distance (2.9182(14) $\AA$ ) exceeds the analogous distances in $\mathbf{1}$ and lies within the interval of values for published data (2.6248(16)2.9206(13) ̊). ${ }^{24,25}$ As one should expect that such an interaction leads to elongation of the $\mathrm{C}(21)-\mathrm{F}(16)$ bond length (1.362(2) ̊) compared to other distances in this $\mathrm{CF}_{3}$-group (1.330(3)-1.339(3) ̊). The steric saturation of the metal coordination sphere by ligands in 3 is 90.5 (2)\% that is less than in 2 . Thus, the steric factors do not prevent the realization of the intramolecular Ce $\cdots \mathrm{F}$ interaction in $\mathbf{3}$ as it is distinct from $\mathbf{1}$. Due to the presence of phenanthroline containing extensive $\pi$-systems, in a crystal of 3 , intermolecular $\pi \cdots \pi$ interactions are realized which combine the molecules in couples (Fig. 2b). The distances between centers of six-membered rings are $3.665 \AA$ and satisfy the geometric criterion for the existence of $\pi-\pi$ interactions $(3.8 \AA)^{26}$ between phenanthroline molecules in neighboring complexes.

Perfluorinated tert-butoxides $\mathbf{4 , 5}$ and diolates $\mathbf{6 ,}$ 7, 8 were prepared similarly to $\mathbf{1 - 3}$. In the reactions with the diol, the molar ratio 2:3 was used. The butoxides contain two molecules of DME whereas diolates have no coordinated solvent at all. LDI-TOF analysis revealed that cerium tert-butoxide is a 
dimer while the gadolinium counterpart has a monomeric structure.

$$
\begin{aligned}
& 2 \mathrm{Ce}\left[\mathrm{N}\left(\mathrm{SiMe}_{3}\right)_{2}\right]_{3}+6 \mathrm{R}^{\prime} \mathrm{OH} \underset{-6 \mathrm{HN}\left(\mathrm{SiMe}_{3}\right)_{2}}{\longrightarrow}\left[\mathrm{Ce}\left(\mathrm{OR}^{\prime}\right)_{3}(\mathrm{DME})_{2}\right]_{2} \\
& \mathrm{Gd}\left[\mathrm{N}\left(\mathrm{SiMe}_{3}\right)_{2}\right]_{3}+3 \mathrm{R}^{\prime} \mathrm{OH} \underset{-3 \mathrm{HN}\left(\mathrm{SiMe}_{3}\right)_{2}}{\longrightarrow}\left\{\mathrm{Gd}\left(\mathrm{OR}_{3}^{\prime}\right)_{3}(\mathrm{DME})_{2}\right\}
\end{aligned}
$$

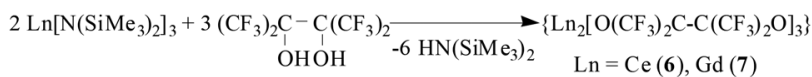

$$
\begin{aligned}
& 2 \mathrm{Ce}\left[\mathrm{N}\left(\mathrm{SiMe}_{3}\right)_{2}\right]_{3}+3\left(\mathrm{CF}_{3}\right)_{2} \mathrm{C}-\mathrm{C}_{1}\left(\mathrm{CF}_{3}\right)_{2}+2 \text { Phen } \underset{-6 \mathrm{HN}\left(\mathrm{SiMe}_{3}\right)_{2}}{\longrightarrow} \\
& \left\{\mathrm{Ce}_{2}\left[\mathrm{O}\left(\mathrm{CF}_{3}\right)_{2} \mathrm{C}-\mathrm{C}\left(\mathrm{CF}_{3}\right)_{2} \mathrm{O}\right]_{3}(\mathrm{Phen})_{2}\right\} \\
& \mathrm{Ce}\left[\mathrm{N}\left(\mathrm{SiMe}_{3}\right)_{2}\right]_{3}+\underset{\mathrm{OHOH}}{2\left(\mathrm{CF}_{3}\right)_{2} \mathrm{C}-\underset{\mathrm{O}}{\mathrm{C}}\left(\mathrm{CF}_{3}\right)_{2}}+2 \text { Phen } \underset{-3 \mathrm{HN}\left(\mathrm{SiMe}_{3}\right)_{2}}{\overrightarrow{\mathrm{O}}} \\
& \left\{\mathrm{Ce}\left[\mathrm{O}\left(\mathrm{CF}_{3}\right)_{2} \mathrm{C}-\mathrm{C}\left(\mathrm{CF}_{3}\right)_{2} \mathrm{OH}\right]\left[\mathrm{O}\left(\mathrm{CF}_{3}\right)_{2} \mathrm{C}-\mathrm{C}\left(\mathrm{CF}_{3}\right)_{2} \mathrm{O}\right](\text { Phen })_{2}\right\}
\end{aligned}
$$

Besides the pale brown product 8 in the last reaction, a negligible amount of mononuclear diolate $\left\{\mathrm{Ce}\left[\mathrm{O}\left(\mathrm{CF}_{3}\right)_{2} \mathrm{C}-\mathrm{C}\left(\mathrm{CF}_{3}\right)_{2} \mathrm{O}\right]\right.$ $\left.\left[\mathrm{O}\left(\mathrm{CF}_{3}\right)_{2} \mathrm{C}-\mathrm{C}\left(\mathrm{CF}_{3}\right)_{2}(\mathrm{OH})\right](\mathrm{Phen})_{2}\right\}$ (9) was isolated as orange crystals. Change of the cerium amide: diol ratio to $1: 2$ resulted in an increase of the yield of 9 up to 59\%. Probably, the reason for formation of such a product is due to a slight excess of alcohol and phenanthroline in the reaction mixture.

According to X-ray analysis complex 9 (Fig. 3a) has a monomeric structure in which the cerium ion is linked to one butanediolate, one hydroxybutanediolate and two phenanthroline ligands. The cerium-oxygen distances of the butanediolate ligand (2.311(4) and 2.344(4) §) are significantly longer than the length of the cerium-oxygen bond of the hydroxybutane-
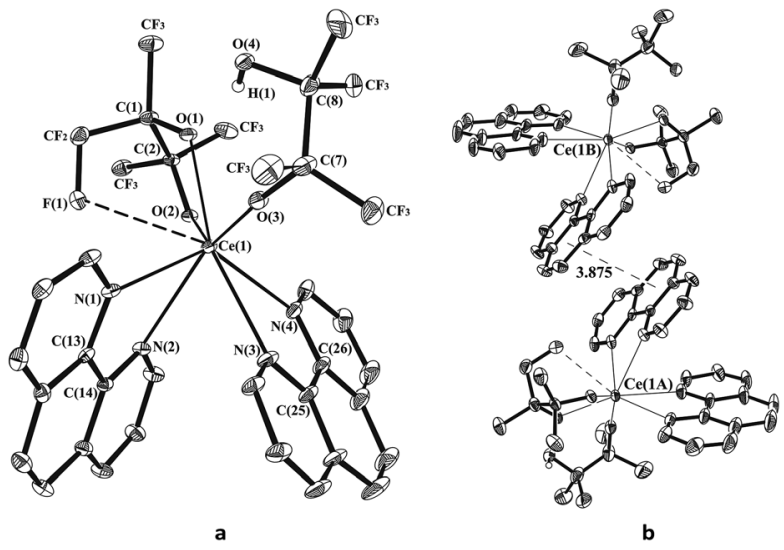

Fig. 3 Molecular structure of 9 (a) and the dimeric structure of 9 in crystal (b). Thermal ellipsoids are drawn at the $30 \%$ probability level. $\mathrm{H}$ atoms are omitted for clarity. Selected distances $[\AA]$ and angles $\left[^{\circ}\right]$ in 9 : $\mathrm{Ce}(1)-\mathrm{O}(3)$ 2.258(5), $\mathrm{Ce}(1)-\mathrm{O}(2)$ 2.311(4), $\mathrm{Ce}(1)-\mathrm{O}(1) 2.344(4), \mathrm{Ce}(1)-\mathrm{N}(2)$ 2.648(5), $\mathrm{Ce}(1)-\mathrm{N}(1) 2.653(6), \mathrm{Ce}(1)-\mathrm{N}(4)$ 2.679(6), $\mathrm{Ce}(1)-\mathrm{N}(3) 2.741(6)$, $\mathrm{Ce}(1)-\mathrm{F}(1) \quad 2.950(4) ; \quad \mathrm{O}(3)-\mathrm{Ce}(1)-\mathrm{O}(2) \quad 136.86(17), \quad \mathrm{O}(3)-\mathrm{Ce}(1)-\mathrm{O}(1)$ 75.95(16), O(2)-Ce(1)-O(1) 66.80(15), O(3)-Ce(1)-N(2) 139.64(18), O(2)$\mathrm{Ce}(1)-\mathrm{N}(2) \quad 83.17(16), \quad \mathrm{O}(1)-\mathrm{Ce}(1)-\mathrm{N}(2) \quad 131.94(16), \quad \mathrm{O}(3)-\mathrm{Ce}(1)-\mathrm{F}(1)$ 115.54(16), O(2)-Ce(1)-F(1) 62.61(15), O(1)-Ce(1)-F(1) 59.63(14), N(1)$\mathrm{Ce}(1)-\mathrm{F}(1)$ 64.77(15), N(3)-Ce(1)-F(1) 137.70(17). diolate group $(2.258(5) \AA)$. Such differences in the bond lengths can be caused by steric effects in the coordination sphere of cerium. In complex $\mathbf{9}$ as for $\mathbf{3}$ there is an intra-

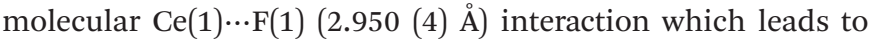
the elongation of the bond $\mathrm{C}(3)-\mathrm{F}(1)(1.353(9) \AA)$ length compared to analogous ones $(1.337(9)-1.341(9) \AA)$. The steric saturation of the metal coordination sphere by ligands in 3 is $87.7(2) \%$. It should be noted that phenanthroline molecules neighboring complexes 9 in the crystal have offset disposition to each other but the distance between the centers of the sixmembered rings of these ligands (3.875 $\AA$ ) slightly exceeds the geometric criterion for the existence of the $\pi-\pi$ interaction (Fig. 3b). ${ }^{26}$

The general properties of alkoxides 4-9 are similar to those of isopropoxides $\mathbf{1}$ and 3: they are slowly hydrolyzed in air, soluble in common organic solvents and do not sublime in vacuo which prevents their application as an emitting material in OLED devices.

As it has been mentioned, $\mathrm{f}-\mathrm{d}$ emission of lanthanide complexes is of considerable interest because of their wide application potential. In an effort to obtain samarium(II) the $\mathrm{f}-\mathrm{d}$ emitter, interaction of $\mathrm{SmI}_{2}$ with potassium isopropoxide KOR was carried out. However, the reaction afforded the complex $\left\{\mathrm{Sm}_{2}\left(\mu_{2}-\mathrm{OR}\right)_{3}\left(\mu_{3}-\mathrm{OR}\right)_{2} \mathrm{Sm}(\mathrm{OR})_{2}(\mathrm{THF})_{2.5}\left(\mathrm{Et}_{2} \mathrm{O}\right)_{0.5}\right\}$ (Fig. 4) containing one $\mathrm{Sm}^{3+}$ and two $\mathrm{Sm}^{2+}$ cations.

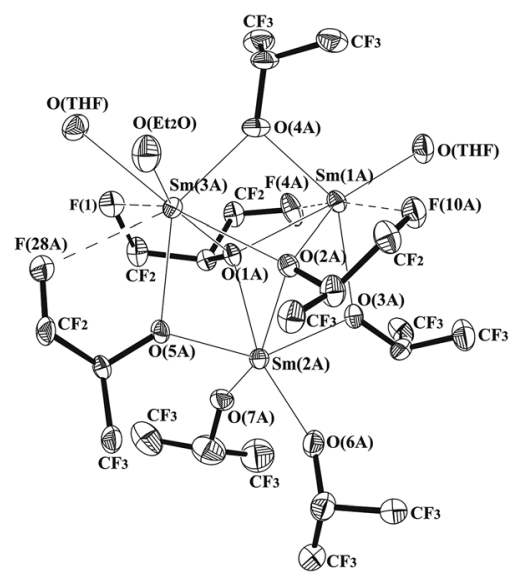

Fig. 4 Molecular structure of 10. Thermal ellipsoids are drawn at the $30 \%$ probability level. $\mathrm{H}$ atoms are omitted for clarity. Selected distances $[A ̊]$ and angles $\left[^{\circ}\right]$ in 10: $\mathrm{Sm}(1 \mathrm{~A})-\mathrm{O}(3 \mathrm{~A}) 2.486(11), \mathrm{Sm}(1 \mathrm{~A})-\mathrm{O}(1 \mathrm{~A}) 2.555(10)$, $\operatorname{Sm}(1 \mathrm{~A})-\mathrm{O}(2 \mathrm{~A}) \quad 2.605(11), \quad S m(1 \mathrm{~A})-\mathrm{F}(10 \mathrm{~A}) \quad 2.720(11), \quad \operatorname{Sm}(1 \mathrm{~A})-\mathrm{F}(4 \mathrm{~A})$ 2.728(10), $\operatorname{Sm}(1 A)-\operatorname{Sm}(2 A) \quad 3.7253(12), \quad \operatorname{Sm}(1 A)-\operatorname{Sm}(3 A) \quad 3.8026(12)$, $\mathrm{Sm}(2 \mathrm{~A})-\mathrm{O}(7 \mathrm{~A}) \quad 2.155(11), \quad \mathrm{Sm}(2 \mathrm{~A})-\mathrm{O}(6 \mathrm{~A}) \quad 2.201(11), \quad \mathrm{Sm}(2 \mathrm{~A})-\mathrm{O}(3 \mathrm{~A})$ 2.350(10), $S m(2 A)-O(5 A) 2.364(10), S m(2 A)-O(2 A) 2.477(11), S m(2 A)-$ $\mathrm{O}(1 \mathrm{~A})$ 2.512(10), $\mathrm{Sm}(2 \mathrm{~A})-\mathrm{Sm}(3 \mathrm{~A})$ 3.7568(11), $\mathrm{Sm}(3 \mathrm{~A})-\mathrm{O}(4 \mathrm{~A})$ 2.410(12), $\mathrm{Sm}(3 \mathrm{~A})-\mathrm{O}(5 \mathrm{~A})$ 2.519(10), $\mathrm{Sm}(3 \mathrm{~A})-\mathrm{O}(2 \mathrm{SA}) 2.590(11), 2.596(5), \mathrm{Sm}(3 \mathrm{~A})-$ $O(2 A) \quad 2.617(11), \quad S m(3 A)-O(1 A) \quad 2.663(10), \quad S m(3 A)-F(28 A)$ 2.894(11); $O(3 A)-S m(1 A)-O(1 A)$ 71.8(3), O(3A)-Sm(1A)-O(4A) 136.0(3), O(1A)$\operatorname{Sm}(1 A)-O(4 A)$ 76.0(4), O(3A)-Sm(1A)-O(2A) 69.0(3), O(1A)-Sm(1A)$O(2 A) \quad 64.5(3), \quad O(4 A)-S m(1 A)-O(2 A) \quad 70.5(4), \quad O(3 A)-S m(1 A)-F(10 A)$ 85.0(4), $O(1 A)-S m(1 A)-F(10 A)$ 125.6(3), O(4A)-Sm(1A)-F(10A) 90.2(4), $O(2 A)-S m(1 A)-F(10 A) \quad 61.3(3), \quad O(1 A)-S m(1 A)-F(4 A) \quad 60.5(3), \quad O(4 A)-$ $S m(1 A)-F(4 A)$ 104.8(4), O(2A)-Sm(1A)-F(4A) 124.0(3), Sm(2A)-Sm(1A)$\mathrm{Sm}(3 \mathrm{~A})$ 59.86(2). 


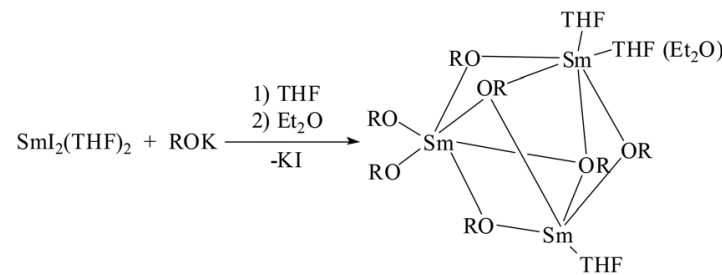

Formation of heterovalent product can be stipulated by the reaction of the formed at initial stage samarium(II) isopropoxide with $\mathrm{ROH}$ which remains after the synthesis of potassium salt and its excess cannot be removed from the reaction solution without decomposition of this salt.

According to the X-ray analysis, the metal atoms in $\mathbf{1 0}$ are linked to each other via $\mu_{2^{-}}$and $\mu_{3}$-isopropoxide ligands. Two terminal OR groups are bonded to the $\mathrm{Sm}^{3+}$ ion. The $\mu_{3}$-oxygen atoms $(\mathrm{O}(1)$ and $\mathrm{O}(2))$ are disposed over and under the plain $\operatorname{Sm}(1) \operatorname{Sm}(2) \operatorname{Sm}(3)$ forming the trigonal-bipyramidal skeleton. Note that there are two independent molecules of $\mathbf{1 0}$ in the asymmetric unit cell. The $\mathrm{Sm}^{2+}$ cations in one of the independent molecules of $\mathbf{1 0}$ are coordinated by three THF molecules whereas in other molecules they are coordinated by one $\mathrm{Et}_{2} \mathrm{O}$ and two THF molecules. Additionally, there are four close contacts between samarium(II) ions and fluorine atoms of $\mu_{3}$-OR ligands in the complex.

Another potential $\mathrm{f}-\mathrm{d}$ emitter - heterobimetallic alkoxide of divalent europium $\left\{\mathrm{Eu}_{2}\left(\mu_{2}-\mathrm{OR}\right)_{3}\left(\mu_{3}-\mathrm{OR}\right)_{2} \mathrm{Y}(\mathrm{OR})_{2}(\mathrm{DME})_{2}\right\} \quad$ (11) was synthesized by the reaction of $\mathrm{Y}\left[\mathrm{N}\left(\mathrm{SiMe}_{3}\right)_{2}\right]_{3}$ and $\mathrm{Eu}\left[\mathrm{N}\left(\mathrm{SiMe}_{3}\right)_{2}\right]_{2}$ with isopropanol in $\mathrm{Et}_{2} \mathrm{O}$ solution. Yttrium was chosen as a sensitizer of europium emission because it can form high-lying ligand-to-metal charge transfer state (LMCT) from which transfer of absorbing energy to resonance levels of Eu(II) may occur. ${ }^{12}$ It should be noted that compound $\mathbf{1 1}$ is the first structurally characterized heterobimetallic complex, which contains yttrium and europium ions (Fig. 5).

$$
\begin{array}{r}
2 \mathrm{Eu}\left[\mathrm{N}(\mathrm{SiMe})_{3}\right]_{2}(\mathrm{DME})_{2}+\mathrm{Y}\left[\mathrm{N}\left(\mathrm{SiMe}_{3}\right)_{2}\right]_{3}+7 \mathrm{ROH} \underset{-7 \mathrm{HN}\left(\mathrm{SiMe}_{3}\right)_{2}}{\longrightarrow}\left\{\mathrm{Eu}_{2}\left(\mu_{2}-\mathrm{OR}\right)_{3}\left(\mu_{3}-\mathrm{OR}\right)_{2} \mathrm{Y}(\mathrm{OR})_{2}(\mathrm{DME})_{2}\right\} \\
\mathbf{1 1}
\end{array}
$$

In spite of the fact that complexes $\mathbf{1 0}$ and $\mathbf{1 1}$ were prepared by different reactions, the molecular structures of these compounds are very similar. Moreover, arrangement of the prepared earlier complexes $\mathrm{Eu}_{3}(\mathrm{OR})_{7}(\mathrm{DME})_{2}$ and $\mathrm{Yb}_{3}(\mathrm{OR})_{7}(\mathrm{THF})\left(\mathrm{Et}_{2} \mathrm{O}\right)^{12}$ appeared to be analogous to that of complexes $\mathbf{1 0}$ and 11. In both complexes one trivalent and two divalent metal cations are linked to each other via three $\mu_{2}$ - and two $\mu_{3}$-isopropoxide ligands. Two terminal OR groups are bonded to $\mathrm{Sm}^{3+}$ (in 10) and $\mathrm{Y}^{3+}$ (in 11) ions. Two coordination sites around each of divalent ions are occupied by $\mathrm{Et}_{2} \mathrm{O}$ and THF molecules in samarium isopropoxide and by DME in europium-yttrium complex. The $\mu_{3}$-oxygen atoms $(\mathrm{O}(1), \mathrm{O}(2)$ in 10 and $\mathrm{O}(10), \mathrm{O}(11)$ in 11) are disposed over and under the plain $\mathrm{Sm}(1) \mathrm{Sm}(2) \operatorname{Sm}(3)(\mathrm{Y}(1) \mathrm{Eu}(1) \mathrm{Eu}(2))$ forming the trigonal-bipyramidal skeleton. Six-membered metallacycle $\operatorname{Ln}_{3} \mathrm{O}_{3}$ in 10 and $\mathbf{1 1}$ is essentially flat. The largest deviation from the plane of atom metallacycle is $0.112 \AA$ in $\mathbf{1 0}$ and $0.191 \AA$ in $\mathbf{1 1}$.

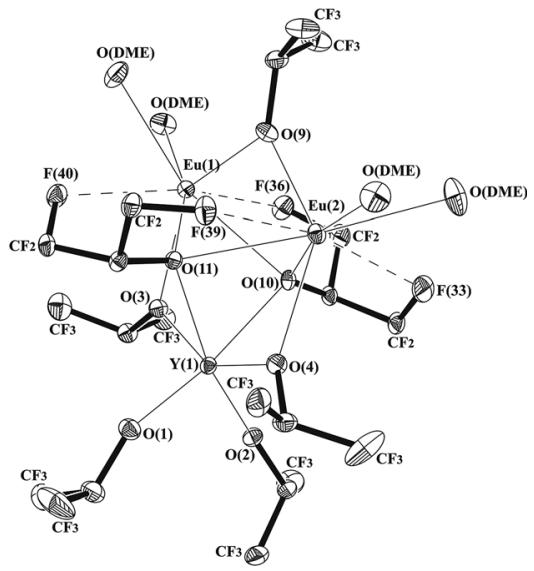

Fig. 5 Molecular structure of 11. Thermal ellipsoids are drawn at the $30 \%$ probability level. $\mathrm{H}$ atoms are omitted for clarity. Selected distances $[\AA ̊]$ and angles [ $\left.{ }^{\circ}\right]$ in 10: $Y(1)-O(2) 2.115(3), Y(1)-O(1) 2.117(3), Y(1)-O(3)$ 2.277(3), $Y(1)-O(4) 2.283(3), Y(1)-O(11) 2.365(3), Y(1)-O(10) 2.370(3), Y(1)-$ $\mathrm{Eu}(1)$ 3.6644(4), $Y(1)-\mathrm{Eu}(2)$ 3.6733(4), $\mathrm{Eu}(1)-\mathrm{O}(9)$ 2.475(3), $\mathrm{Eu}(1)-\mathrm{O}(11)$ 2.525(3), $\mathrm{Eu}(1)-\mathrm{O}(3)$ 2.546(3), $\mathrm{Eu}(1)-F(36) 2.662(2), \mathrm{Eu}(1)-\mathrm{O}(10) 2.760(3)$, $\mathrm{Eu}(1)-\mathrm{F}(40)$ 2.857(2), $\mathrm{Eu}(1)-\mathrm{Eu}(2)$ 3.8602(3), $\mathrm{Eu}(2)-\mathrm{O}(9)$ 2.473(3), $\mathrm{Eu}(2)-$ $\mathrm{O}(4)$ 2.530(3), $\mathrm{Eu}(2)-\mathrm{O}(10) 2.536(3), \mathrm{Eu}(2)-F(39)$ 2.678(2), $\mathrm{Eu}(2)-\mathrm{O}(11)$ 2.811(3), $\mathrm{Eu}(2)-F(33)$ 2.974(3); $\mathrm{O}(2)-\mathrm{Y}(1)-\mathrm{O}(1)$ 99.51(11), $\mathrm{O}(2)-\mathrm{Y}(1)-\mathrm{O}(3)$ 95.43(11), O(1)-Y(1)-O(3) 106.76(11), O(3)-Y(1)-O(4) 148.63(10), O(2)$Y(1)-O(11) \quad 165.27(10), \quad O(1)-Y(1)-O(11) \quad 94.95(10), \quad O(3)-Y(1)-O(11)$ 77.57(9), O(4)-Y(1)-O(11) 76.07(9), O(2)-Y(1)-O(10) 94.32(10), O(1)-Y(1)$\mathrm{O}(10)$ 165.17(10), O(11)-Y(1)-O(10) 71.59(9), O(9)-Eu(1)-O(11) 75.60(9), $\mathrm{O}(9)-\mathrm{Eu}(1)-\mathrm{O}(3)$ 134.29(9), O(11)-Eu(1)-O(3) 70.00(8), O(9)-Eu(1)-F(36) 89.58(9), O(3)-Eu(1)-F(36) 84.05(8), O(11)-Eu(1)-O(10) 63.01(8), F(36)$\mathrm{Eu}(1)-\mathrm{F}(40) 165.34(8)$.

The $\mathrm{Sm}^{3+}-\mu_{2}-\mathrm{O}$ distances $(2.340(11)-2.364(10) \AA)$ in 10 are somewhat shorter than the lengths of analogous $\mathrm{Sm}^{2+}-\mu_{2}-\mathrm{O}$ (2.410(12)-2.571(13) $\AA$ ) due to a smaller radius of the $\mathrm{Sm}^{3+}$ ion compared to the $\mathrm{Sm}^{2+}$ one $(1.098(\mathrm{CN}=6), 1.360(\mathrm{CN}=7)$ and $1.410(\mathrm{CN}=8) \AA$ respectively $).{ }^{27}$ The $\mathrm{Sm}^{3+}-\mathrm{O}$ distances (2.116(11)-2.364(10) are in agreement with analogous ones in 1 (2.130(5)-2.408(3) A). The intramolecular $\mathrm{Sm}^{2+}$...F distances in $10(2.697(9)-2.906(10) \AA)$ are located within the range of published $\mathrm{Sm} \cdots \mathrm{F}$ interactions ${ }^{21,22}$ or slightly longer, however this does not lead to an appreciable elongation of $\mathrm{C}-\mathrm{F}$ distances in $\mathrm{CF}_{3}$-groups.

The $\mathrm{Y}^{3+}-\mathrm{O}$ distances $(2.115(3)-2.370(3) \AA)$ are somewhat shorter than the lengths of the analogous $\mathrm{Eu}^{3+}-\mathrm{O}$ bonds in $\mathrm{Eu}_{3}(\mathrm{OR})_{7}(\mathrm{DME})_{2}(2.160(4)-2.437(4) \AA)$. The Y...Eu (3.6644(4), 3.6733(4) ̊) distance is also somewhat smaller than the Eu...Eu distance $(3.8602(3) \AA)$ due to a smaller radius of $\mathrm{Y}^{3+}$ compared to the $\mathrm{Eu}^{2+}$ ion $(1.040(\mathrm{CN}=6)$ and $1.390(\mathrm{CN}=8) \AA$ respectively). ${ }^{27}$ The $\mathrm{Eu}^{2+}-\mu_{2}-\mathrm{O}$ and $\mathrm{Eu}^{2+}-\mu_{3}-\mathrm{O}$ distances vary in the range of 2.473(3)-2.546(3) $\AA$ and 2.525(3)-2.811(3) $\AA$ respectively. These bond lengths in $\mathbf{1 1}$ are in agreement with analogous ones in $\mathrm{Eu}_{3}(\mathrm{OR})_{7}(\mathrm{DME})_{2}\left(\mathrm{Eu}^{2+}-\mu_{2}-\mathrm{O} 2.469(4)-2.532(3)\right.$ $\AA$ and $\left.\mathrm{Eu}^{2+}-\mu_{3}-\mathrm{O} 2.513(4)-2.740(4) \AA\right)$. As with complex $\mathrm{Eu}_{3}(\mathrm{OR})_{7}(\mathrm{DME})_{2}$ the intramolecular $\mathrm{Eu}^{2+} \ldots \mathrm{F}$ interactions are realized in complex 11. The $\mathrm{Eu}^{2+} \ldots \mathrm{F}(2.662(2)-2.974(3) \AA)$ distances are close to analogous ones in $\mathrm{Eu}_{3}(\mathrm{OR})_{7}(\mathrm{DME})_{2}$ complex (2.699(4)-2.920(4) ̊). 
It is interesting to note that among the prepared alkoxides 1, 3, and 9-11 where intramolecular Ln $\cdots \mathrm{F}$ interactions are observed, the steric saturation of the metal coordination sphere varies in the range of $87.7(2)-94.9(2) \%$. In turn, in complex 2 where such interactions are absent, the G-parameter (97.3 (2)\%) significantly exceeds the analogous values for the complexes with close Ln-F contacts.

\section{Luminescent properties}

Among the prepared complexes, PL was observed for the europium-yttrium isopropoxide and all the cerium derivatives. Acetonitrile solutions of cerium compounds $\mathbf{4}$ and $\mathbf{6}$ showed emission in the region of 370-400 $\mathrm{nm}$ (Fig. 6). These bands exhibit multimodal character and each of them can be decomposed into two Gaussian peaks with maxima at 343, 373 and 392, $425 \mathrm{~nm}$ respectively. The energy difference between these peaks is close to $2000 \mathrm{~cm}^{-1}$, in good agreement with the characteristic splitting of the two $\mathrm{Ce}^{3+} 4 \mathrm{f}$ ground levels induced by the spin-orbit interaction. $^{28}$ Therefore, the PL of $\mathbf{4}$ and $\mathbf{6}$ is attributed to the electric-dipole $4 \mathrm{~d} \rightarrow 5 \mathrm{f}$ transitions in the cerium ion from the lowest excited state ${ }^{2} \mathrm{D}_{3 / 2}$ to the ground states ${ }^{2} \mathrm{~F}_{5 / 2}$ and ${ }^{2} \mathrm{~F}_{7 / 2}$.

Besides, the $\mathrm{f}-\mathrm{d}$ emission of the $\mathrm{Ce}^{3+}$ ion was observed for complexes 3, 8 and 9 (Fig. 7). Comparison of the PL spectra of 6 and 8 shows that insertion of the phenanthroline ligand in the cerium butanediolate caused slight blue shifting of the emission maximum from 410 to $405 \mathrm{~nm}$ and decreasing PL intensity.

Heterobimetallic complex $\mathbf{1 1}$ revealed blue PL with a maximum at $485 \mathrm{~nm}$ (Fig. 8). As the compound does not contain chromophore ligands and the band of emission lies in the range of $\mathrm{Eu}^{2+}$ luminescence, ${ }^{10}$ so the observed peak was attributed to $4 \mathrm{f}^{6} 5 \mathrm{~d}^{1} \rightarrow 4 \mathrm{f}^{7}$ transition in the europium(II) ion.

Interestingly, complexes $\mathbf{3}$ and $\mathbf{1 1}$ did not reveal luminescence in MeCN solution in contrast to THF medium probably
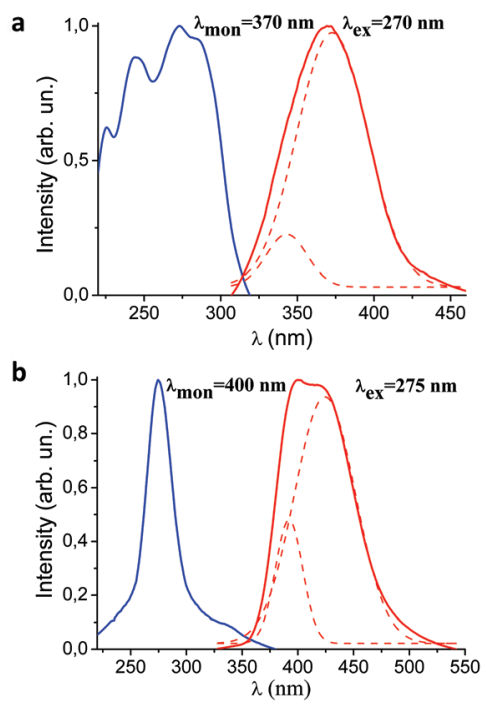

Fig. 6 Excitation (blue) and emission (red) spectra of complexes 4 (a) and 6 (b) in MeCN solutions, and Gaussian fits for the emission spectra of the alkoxides (red dashed lines).

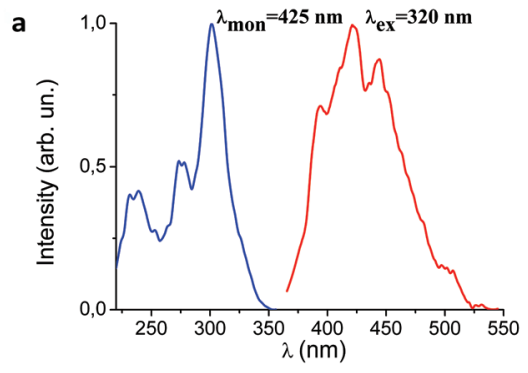

b

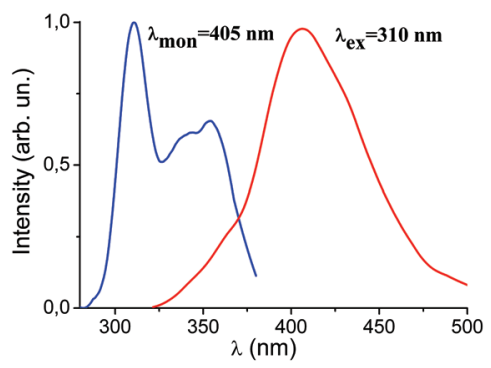

c

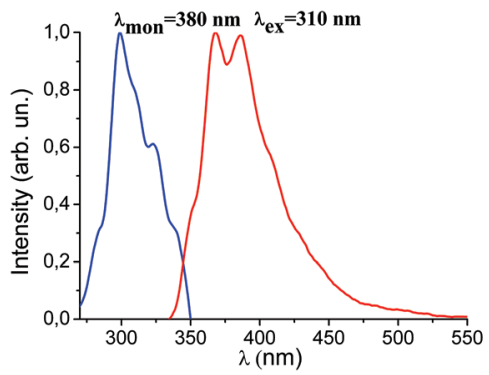

Fig. 7 Excitation (blue) and emission (red) spectra of complexes 3 (a) in THF, 8 (b) and 9 (c) in MeCN solution.

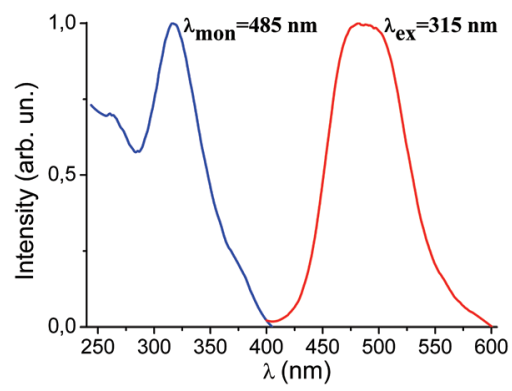

Fig. 8 Excitation (blue) and emission (red) spectra of THF solution of complex 11.

because of differences in the symmetry of the crystal field at cerium atoms in these solvents.

As noted above, due to low volatility and thermal stability of the majority of the prepared complexes, the only OLED device based on isopropoxide 3 was fabricated. A simple three-layered device of structure ITO/TPD/complex 3/BATH/Yb was prepared by the vacuum evaporation method. The diode displayed weak orange luminescence, the spectrum of which contained a single broad band with the maximum at $620 \mathrm{~nm}$ (Fig. 9). The EL efficiency did not exceed $2 \mathrm{~cd} \mathrm{~m}^{-2}$ at $30 \mathrm{~V}$. 


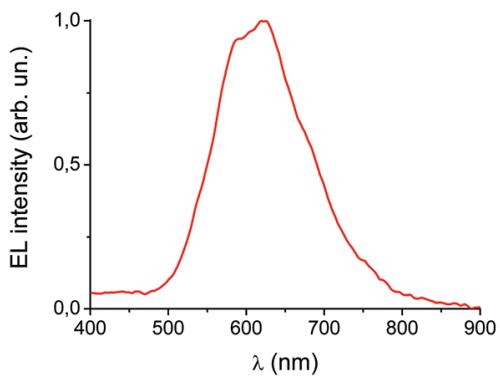

Fig. 9 EL spectrum of OLED of structure ITO/TPD/complex 3/BATH/ $\mathrm{Yb}$.

The observed EL can be ascribed to the emission of the electroplex formed at the TPD/3 interface. Confirmation of the supposition is the absence of PL of the double layer and blend TPD-3 samples. Similar EL of electroplex was registered previously for the OLED devices based on the lanthanide pentafluorophenolates. $^{29}$

\section{Conclusions}

A set of $\mathrm{Ce}(\mathrm{III}), \mathrm{Sm}(\mathrm{II})(\mathrm{III}), \mathrm{Eu}(\mathrm{II}), \mathrm{Gd}(\mathrm{III})$ and $\mathrm{Yb}(\mathrm{III})$ complexes with fluorinated isopropoxide, tert-butoxide and butanediolate ligands was prepared. X-ray and LDI-TOF analysis revealed that Ln(III) isopropoxides as well as Ce tert-butoxide have binuclear arrangement whereas gadolinium butoxide is mononuclear probably due to a smaller radius of the $\mathrm{Gd}^{3+}$ ion. Isostructural alkoxides $\mathbf{1 0}$ and $\mathbf{1 1}$ are trinuclear clusters in which two $\mathrm{Ln}^{2+}$ cations are bonded via bridging RO ligands to the $\mathrm{Sm}^{3+}$ cation (in 10) or the $\mathrm{Y}^{3+}$ cation (in 11). All the prepared cerium complexes upon UV excitation showed short-wavelength emission at the region of $370-425 \mathrm{~nm}$ as broadened bands, which is characteristic for $5 \mathrm{~d} \rightarrow 4 \mathrm{f}$ transitions in the cerium ion. ${ }^{30}$ Heterobimetallic alkoxide $\mathbf{1 1}$ revealed blue PL with a maximum at $485 \mathrm{~nm}$ which was assigned to $\mathrm{f}-\mathrm{d}$ emission of the europium(II) ion. Attempts to prepare OLED devices using the synthesized alkoxides as emitter layers for investigation of their EL properties failed because of low thermal stability of the compounds. The only complex, on the basis of which we were able to design a diode, was cerium compound 3 but this device displayed the electroplex luminescence and not the metal-centered emission.

\section{Acknowledgements}

This work was supported by the Russian Foundation for Basic Research (projects 13-03-00097, 14-03-31043, 15-33-20296).

\section{Notes and references}

1 J. Kido and Y. Okamoto, Chem. Rev., 2002, 102, 2357-2368; J.-C. G. Bunzli and C. Piguet, Chem. Soc. Rev., 2005, 34,
1048-1077; M. A. Katkova, A. G. Vitukhnovskii and M. N. Bochkarev, Russ. Chem. Rev. (Engl. Transl.), 2005, 74, 1089-1109; G. F. de Sa, O. L. Malta, C. de Mello Donega, A. M. Simas, R. L. Longo, P. A. Santa-Cruz and E. F. da Silva Jr., Coord. Chem. Rev., 2000, 196, 165-195.

2 J. Shinar and R. Shinar, J. Phys. D: Appl. Phys., 2008, 41, 133001; S. Landgraf, J. Biochem. Biophys. Methods, 2004, 61, 125-134; H. van Santen and J. H. M. Neijzen, Jpn. J. Appl. Phys., 2003, 42, 1110-1112.

3 C. Canevali, M. Mattoni, F. Morazzoni, R. Scotti, M. Casu, A. Musinu, R. Krsmanovic, S. Polizzi, A. Speghini and M. Bettinelli, J. Am. Chem. Soc., 2005, 127, 14681-14691; C. Tang, Y. Bando, D. Golberg and R. Ma, Angew. Chem., Int. Ed., 2005, 44, 576-579; L. Guerbous and O. Krachni, J. Mod. Opt., 2006, 53, 2043-2053.

4 P. Dorenbos, J. Lumin., 2003, 104, 239-260.

5 T. Yu, W. Su, W. Li, R. Hua, B. Chu and B. Li, Solid-State Electron., 2007, 51, 894-899.

6 W. Li, T. Mishima, G.-Y. Adachi and J. Shiokawa, Inorg. Chim. Acta, 1987, 130, 277-281.

7 H. Kunkely and A. Vogler, J. Photochem. Photobiol., A, 2002, 151, 45-47.

8 X.-L. Zheng, Y. Liu, M. Pan, X.-Q. Lu, J.-Y. Zhang, C.-Y. Zhao, Y.-X. Tong and C.-Y. Su, Angew. Chem., Int. Ed., 2007, 46, 7399-7403.

9 A. Strasser and A. Vogler, Inorg. Chim. Acta, 2004, 357, 2345-2348.

10 J. Jiang, N. Higashiyama, K. Machida and G. Adachi, Coord. Chem. Rev., 1998, 170, 1-29.

11 C. P. Shipley, S. Capecchi, O. V. Salata, M. Etchells, P. J. Dobson and V. Christou, Adv. Mater., 1999, 11, 533-536.

12 D. M. Kuzyaev, R. V. Rumyantsev, G. K. Fukin and M. N. Bochkarev, Russ. Chem. Bull. Int. Ed., 2014, 63, 848-853.

13 P. B. Glover, A. P. Bassett, P. Nockemann, B. M. Kariuki, R. Van Deun and Z. Pikramenou, Chem. - Eur. J., 2007, 13, 6308-6320.

14 W. D. Buchanan and K. Ruhlandt-Senge, Chem. - Eur. J., 2013, 19, 10708-10715; W. D. Buchanan, M. A. Guino-o and K. Ruhlandt-Senge, Inorg. Chem., 2010, 49, 7144-7155.

15 P. Girard, J. L. Namy and H. B. Kagan, J. Am. Chem. Soc., 1980, 102, 2693-2698.

16 T. D. Tilley, R. A. Andersen and A. Zalkin, Inorg. Chem., 1984, 23, 2271-2276.

17 M. N. Bochkarev and A. V. Protchenko, Equip. Exp. Tech., 1990, 1, 194-195.

18 K. S. Mazdiyasni and B. J. Schaper, J. Less-Common Met., 1973, 30, 105-112; D. C. Bradley, H. Chudzynska, M. E. Hammond, M. B. Hursthouse, M. Motevalli and W. Ruowen, Polyhedron, 1992, 11, 375-379.

19 K. K. Yan, G. Schoendorff, B. M. Upton, A. Ellern, T. L. Windus and A. D. Sadow, Organometallics, 2013, 32, 1300-1316.

20 B. Liu, T. Roisnel, L. Maron, J.-F. Carpentier and Y. Sarazin, Chem. - Eur. J., 2013, 19, 3986-3994.

21 W. J. Evans, K. J. Forrestal, M. A. Ansari and J. W. Ziller, J. Am. Chem. Soc., 1998, 120, 2180-2181. 
22 S. Bannerjee, T. J. Emge and J. G. Brennan, Inorg. Chem., 2004, 43, 6307-6312.

23 A. Guzei and M. Wendt, J. Chem. Soc., Dalton Trans., 2006, 3991-3999.

24 H. Yin, J. R. Robinson, P. J. Carroll, P. J. Walsh and E. J. Schelter, Chem. Commun., 2014, 50, 3470-3472.

25 D. Werner, G. B. Deacon, P. C. Junk and R. Anwander, Chem. - Eur. J., 2014, 20, 4426-4438.

26 C. Janiak, J. Chem. Soc., Dalton Trans., 2000, 3885-3896.
27 R. D. Shannon, Acta Crystallogr., Sect. A: Cryst. Phys., Diffr., Theor. Gen. Cryst., 1976, 32, 751-767.

28 S. T. Frey and W. DeW. Horrocks Jr., Inorg. Chem., 1991, 30, 1073-1079.

29 A. P. Pushkarev, V. A. Ilichev, A. A. Maleev, A. A. Fagin, A. N. Konev, A. F. Shestakov, R. V. Rumyantzev, G. K. Fukin and M. N. Bochkarev, J. Mater. Chem. C, 2014, 2, 1532-1538.

30 A. Vogler and H. Kunkely, Inorg. Chim. Acta, 2006, 359, 4130-4138. 